\title{
Ex Uno Lapide: The making present of absence
}

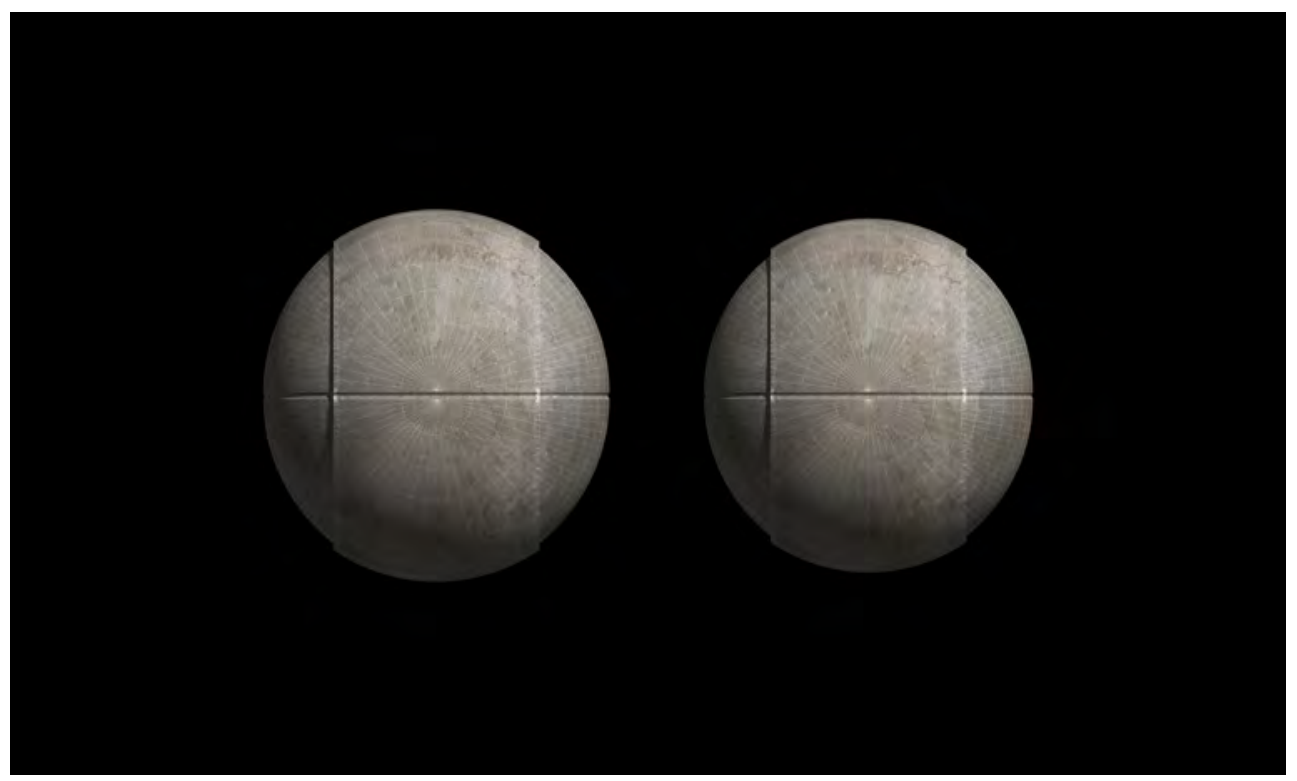

Fig. 1 Ephraim Joris (2018). Primary volume [Computer generated drawing: Joris/AP Valletta]

\section{Background to the research}

The principle of ex uno lapide was a topos of classical literature (Barry, 2019: 57-72), which first appeared in Alberti's treatise on sculpture (Lavin, 1998: 194). Alberti's writing develops observations by Diodorus Siculus on the proportion system of Egyptian sculptors (195). The principle of ex uno lapide can be found in Michelangelo's preliminary sketches preserved in the archives of the Casa Buonarotti Foundation, which represent quarried marble blocks in outline with indications of the future sculptural groups to be carved (193). Also referencing ex uno lapide through the use of a monolithic block in a digital drawing space, the Monolith Drawing, ${ }^{1}$ described below and in the following drawings, correspondingly exists as a study of architecture seemingly in search of ancestral origins-the place where we discover architecture. This urge to (re)discover classical architecture stems from a desire to participate in a renewal of the world, not through post-classicism but through the idea of loss with which we nurture our intuitive understanding of the momentum of history. With this we seek a particular notion of history, acknowledging the fact that history is not merely a moving-on but more like a dwelling in (or through) all time that has passed. We ask here how to design architecture through historical recollection? As such, the Monolith Drawing is never in search of singular historical referents; rather, it looks for a general engagement with history. 
In this paper we comment on the "Monolith Drawing", whose drawing protocol is outlined in the first part. In this part we describe how an architectural figure is extracted out of a single volume, thereby synchronising analogue thinking with computational development. We argue that by this means, entry to history is made possible through our capacity to long for the experience of something that is absent. This argument rests on a Lacanian notion that there cannot be absence in an objective world, since absence can only exist through symbolic or representative means (see Saint-Cyr, 2012), an interpretation that takes the research from the figural towards the spatial. It is through the representational means of the Monolith Drawing that we enable ourselves, as architects, to design presence where there is none, an attempt that amounts to making present absence itself (see Joris, 2015: 213 and also Joris, 2016a).

\section{Extracting the Architectural Figure}

The Monolith Drawing investigates how to design architecture through historical recollection, as opposed to reaffirming existing historical interpretations. The emphasis on recollection here aims to draw on its dynamic and inevitably non-linear qualities. The Monolith Drawing, in turn, envisages a place where relations are drawn as intersecting solids through the repetition of subtractions, cutting into one another, to recompose and eventually create new formal conditions. Each repeated subtraction acknowledges the existing volumes, however, they inevitably modify them, uncovering new possibilities through a removal process of what exists. By this means, creation of form rests on the renegotiation of relationships between forms rather than on the assemblage of pre-existing archetypical elements. This is accentuated by the fact that there are no walls or floors, even with the transcription of void within a lithic core (the equivalent of a solid piece of stone in a digital drawing environment). As such, no real entrance is ever made, nor a real exit achieved. Instead, compositional variability is explored during the subtraction process with the aim of uncovering differential intensities that underlie the process of lithic subtraction itself. In this way the process produces compositional identities-what can be thought of as architectural precursors-where the individuality or clarity of any architectural object is inseparable from the different series of compositional transmutations underpinning it. Hence, while the process stands in service of the creation of interior space, it is really about entering matter. The procedural subtraction process structuring the Monolith Drawing in fact rethinks the objective reality of entrance-forming by reconceiving interiority itself as entrance into dynamic recollection.

The following drawing set illustrates the systematic process of lithic reduction forming the Monolith. They indicate how a retrieving of history, indeed a repossession of time itself, was enacted. Scrutinising the formation of the Monolith in this way allows for a visualization of how time working through time is possible. Starting with a certain appeal to materiality to better induce consciousness of a particular place in time, the drawings in turn communicate the process of an evolving consciousness of this materiality. This gently erases the a priori sense of an object as a fixed entity by allowing a more sensorial relationship. Emphasising the embodied nature of perception, the observer and author of the drawing inevitably become enmeshed with the drawing much as we are enmeshed with the larger world constituting author and drawing. Called on by the Monolith 
then-with its process of projection and subtraction, acting and responding, making and unmaking - is something akin to the crafting and occupying of time. Certainly, at stake is less an occupying of space (although one is inevitably part of a single space of viewing), than a temporal occupancy necessary to the emergence of new architectonic conditions. Caught partially between absence and presence, the Monolith Drawing progresses according to acts of remembering. ${ }^{2}$

The spatial intentional of the Monolith as an initial volume is to suggest the creation of 'room' via subtraction. This is given through of a slow process of 'carving into stone' as the antithesis of composing architecture by means of elements such as columns and beams. The Monolith, as cutout 'stone architecture' enacts a correspondence between form and structure. As such, the expressive value of its form is a direct result of its structural capacity. Vaults, domes and spheres as potential or latent primary volumes thus play an important role.

The Monolith Drawing starts with the composition of a primary volume or what amounts to a lithic-like core. In this initial drawing, the core is sphere-like, due to an implicate integrity of that form bestowed historically. As such, the core recalls certain archetypical forms, or, as Carl Jung has characterised this association, a "psychic residua of innumerable experiences of the same type" (1922: 415). The act of sculpting into the lithic-core follows principles of stereotomy, a process by which the lithic body is doubled to introduce a second intersecting volume. This volume is always and inevitably smaller, much as gazing at one's own reflection necessitates a certain distance. Such distance determines the factor by which the reflected counterpart is scaled. By increasing the distance between the lithic core and its mirror image, the size of the latter will decrease (see Fig 2).

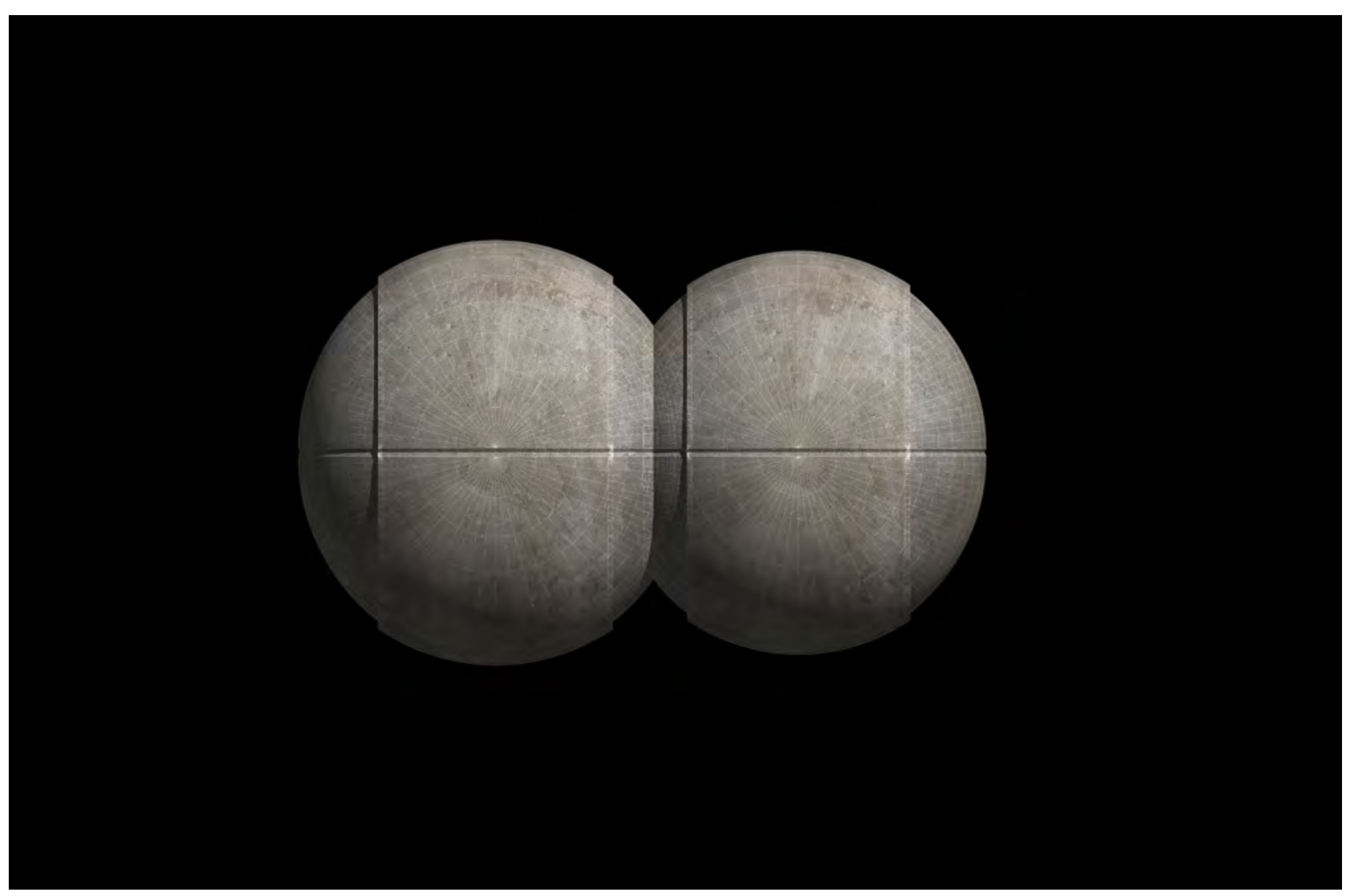


In turn, the subtraction process is initiated by identifying an overlap or intersection between the lithic-core and its reflection. The area of intersection between two solids describes what will become void after the mirror image is subtracted from its original (see Figs. 3 and 4).

Fig. 3 Ephraim Joris (2018). Part removal of the lithic core [Computer generated drawing: Joris/AP Valletta]

Fig. 4 Ephraim Joris (2018). Monolith 14c-a7 [-155 8] after subtraction [Computer generated drawing: Joris/ AP Valletta]
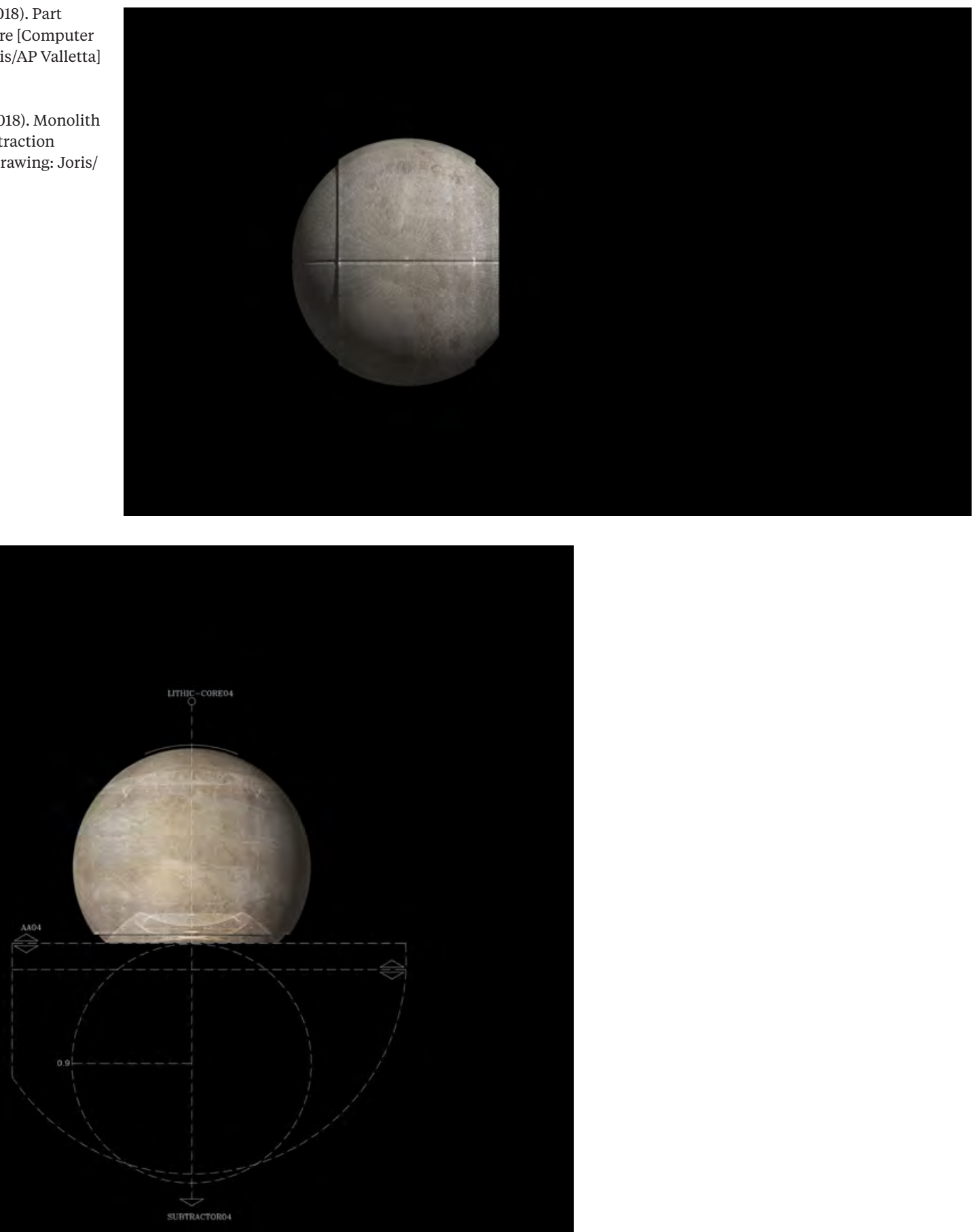

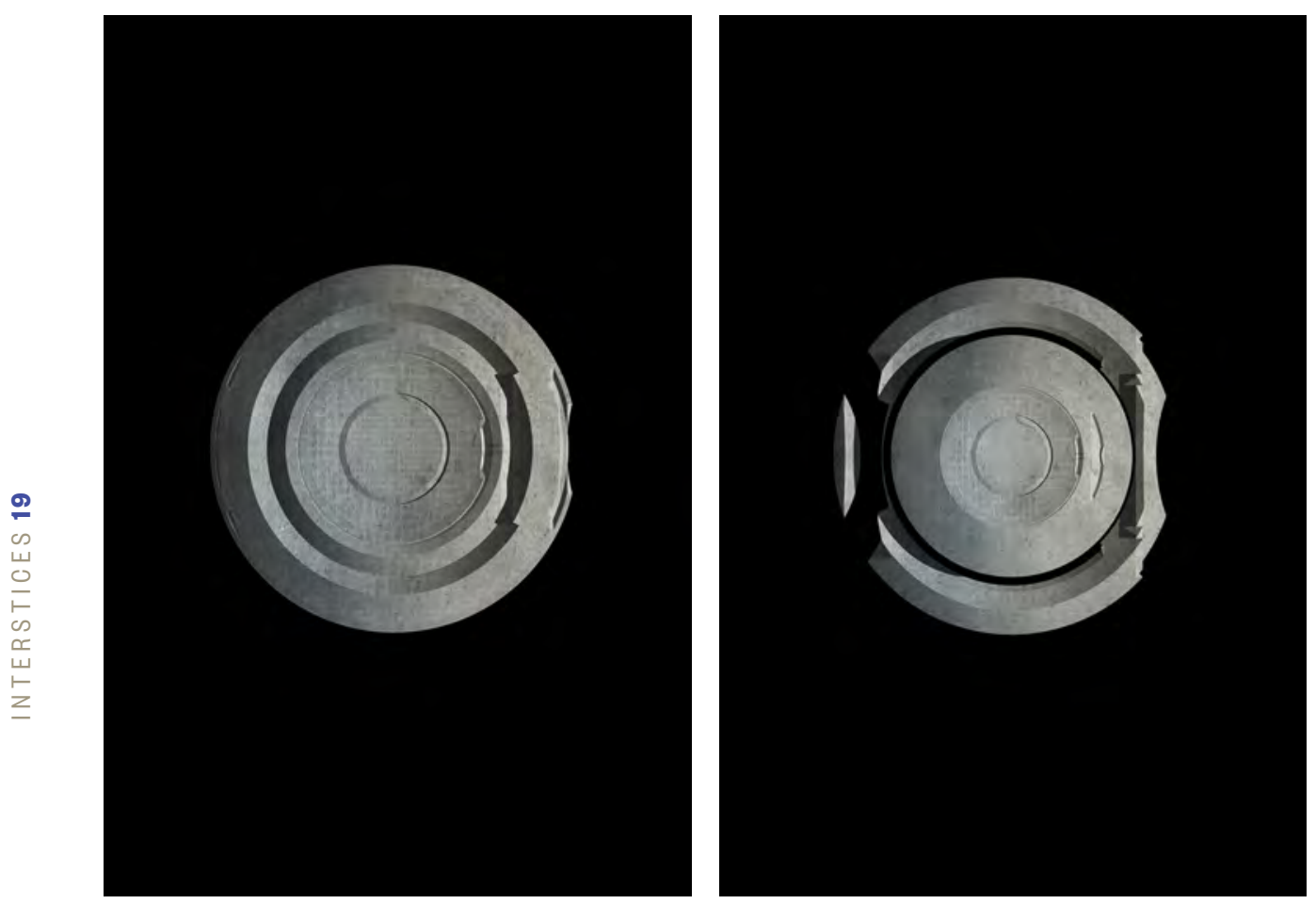

Figs. 5 and 6 Ephraim Joris (2018). Monolith 16-10, Monolith 16-10.5 [Computer generated drawing: Joris/ AP Valletta]
The guiding principle of ex uno lapide allows architecture to be thought about through the solidity and integrity of a single volume out of which spaces are carved. This stands in contrast to algebraic architecture where the idea of building is understood as the assembly of parts. Thus, the Monolith Drawing, negotiates the creation of architecture through a distribution of voids which in turn produce space and structure simultaneously. Nevertheless, continuing the process of mirroring and subsequent subtraction, a point of collapse is eventually reached, one where the lithic body is little more than a collection of shreds and slivers. Along the way, residual Monolith Drawings make up intermediate images leading towards this moment of collapse.

In figures 5 and 6 are seen an elevation sequence looking into the zone of subtraction as partially revealed in the previous diagram (Fig. 4). The process of reflection and subtraction is a cyclical process in which the lithic core receives multiple carvings from subsequent mirror images, each time leaving a recess or exedra subsequent to the subtraction. The process leads to the formation of openings or mouths accessing vacated space within the Monolith or lithic core itself. Still, even with this transcription of voids within the lithic core, no real entrances are made, nor are actual exits formed. Instead, different degrees of compositional intensity are explored during the subtraction process.

Nevertheless, imposition of exedra upon exedra eventually excavates interior spaces within the lithic core-space in fact that can only be accessed as if through the recurring arches of archivolts (see Fig. 7).

Curiously, this ongoing extraction results in an eventual disappearance of the numerous inscriptions or embrasures forming around each void. As such these features seem analogous with ancient principles of ornamentation such as the blind doorways of the Pre-classic Mesoamerican Olmecs (ca. 2000BC) (Stross, 1996: 83-84), the seven Osirian doorways of the Temple of Osiris Hek-Djet in 

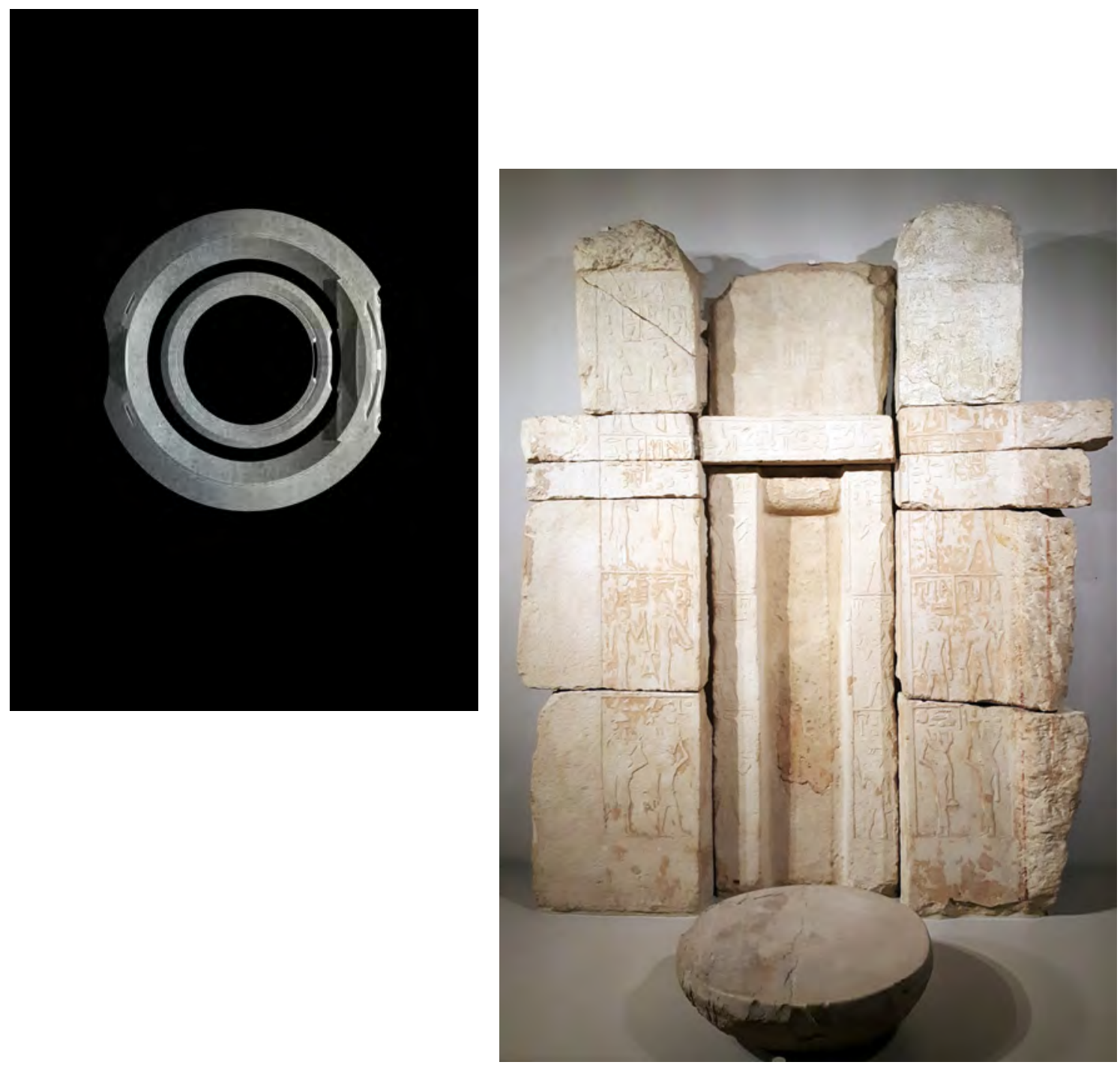

Fig. 7 Ephraim Joris (2018). Monolith 16-11 [Computer generated drawing, Joris/AP Valletta]

Fig. 8 Anonymous (2543-2435 BC) False-Door Stela of Princess Wehemnefret [Photo: Museo Egizio, Torino]
Karnak (ca. 900BC), or, the False-Door Stela of Princess Wehemnefret (2543-2435 BC-see Fig. 8). Interestingly, all such doorways are said to facilitate entrances to various underworlds.

Following similar analogous associations, similarities with the Romanesque portals of the twelfth centuries are evident-for instance, the South porch portal of St Peter's church in Moissac (ca. 1115-30), the triple portal of St Jacques' church in Aubeterre sur Dronne (consecrated 1171), or, the church of St Trophime in Arles (ca. 1190). Despite these similitudes, the Monolith never induces such references directly, since the drawing system eschews ornamentation as a design intention. Instead, the Monolith Drawing produces an architectonic reflective of specific drawing rituals in which ancient production techniques such as stereotomy and ex uno lapide were key.

The Monolith Drawing thus processes form through the renegotiation of ancient production techniques (Emmons, Kassem, 2014), without directly referencing specific styles or types of ornament. The resulting Monoliths exist outside actual systems of historical classification and taxonomy, remaining, in this sense, somewhat anachronistic. It is as if time has been misplaced in the object. Such 
a system of drawing is inherently unstable, always in a process of nascence as Jean-Luc Nancy has described (1993: 4), and given the constant fragmentation, it is without singular identity. In this way, the Monolith Drawing resists the predominant modern ethos of progress, defined as it is in terms of movement towards ideals. It is instead expressive of incessant mutation-an architecture of becoming by means of serial projections and subtractions. The Monolith Drawing persists as a reflective instrument resistive of intentional representational ends, or, stylistic clichés. While dislocating form from its traditional associational meanings or symbolic values, it doesn't deny the presence of such values either-a mode of indifference Peter Eisenman has argued for in a different context (1999: 205-211). The diagrammatic qualities of the Monolith Drawing simply allow the articulation and study of a field of intersectional forces, forces that are themselves unintentionally suggestive.

\section{From the figural towards the architectural: Ex Uno Lapide}

The commission in 2013 of a new extension for the museum of St John's co-Cathedral in Valletta, Malta (dedicated 1578), provided an ideal opportunity to develop an architectural interpretation of the Monolith Drawing research. The co-Cathedral (see Figs. 9 and 10) sits at the heart, both physically and symbolically, of the fortified city of Valletta, itself a manifestation of faith conceived according to Renaissance humanist principles as a bastion of Catholicism in the 16th century Mediterranean (see Tunbridge, 2009 and Pollack, 2010). The com-

Fig. 9 Guillaume Dreyfuss. Main façade of St John's co-Cathedral, Malta [Photograph]

Fig. 10 Guillaume Dreyfuss. Side elevation of St John's co-Cathedral Museum, Malta [Photograph] mission for a design incorporating the rehabilitation and extension of the current museum, in addition to restoring and reusing the neglected and underutilised historical spaces annexed to the co-Cathedral, included a stone enclosure intended to exclusively house a precious set of tapestries.
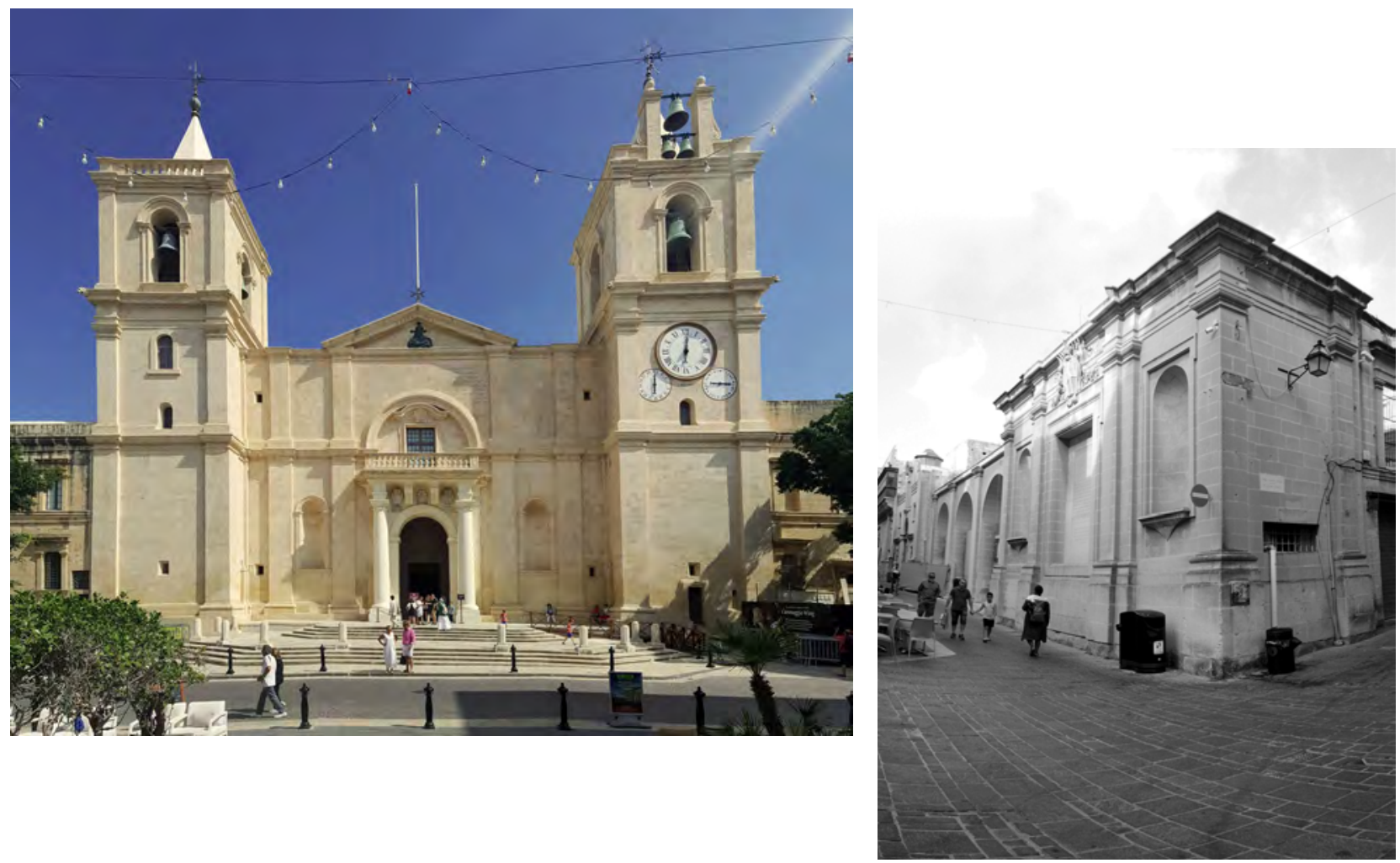


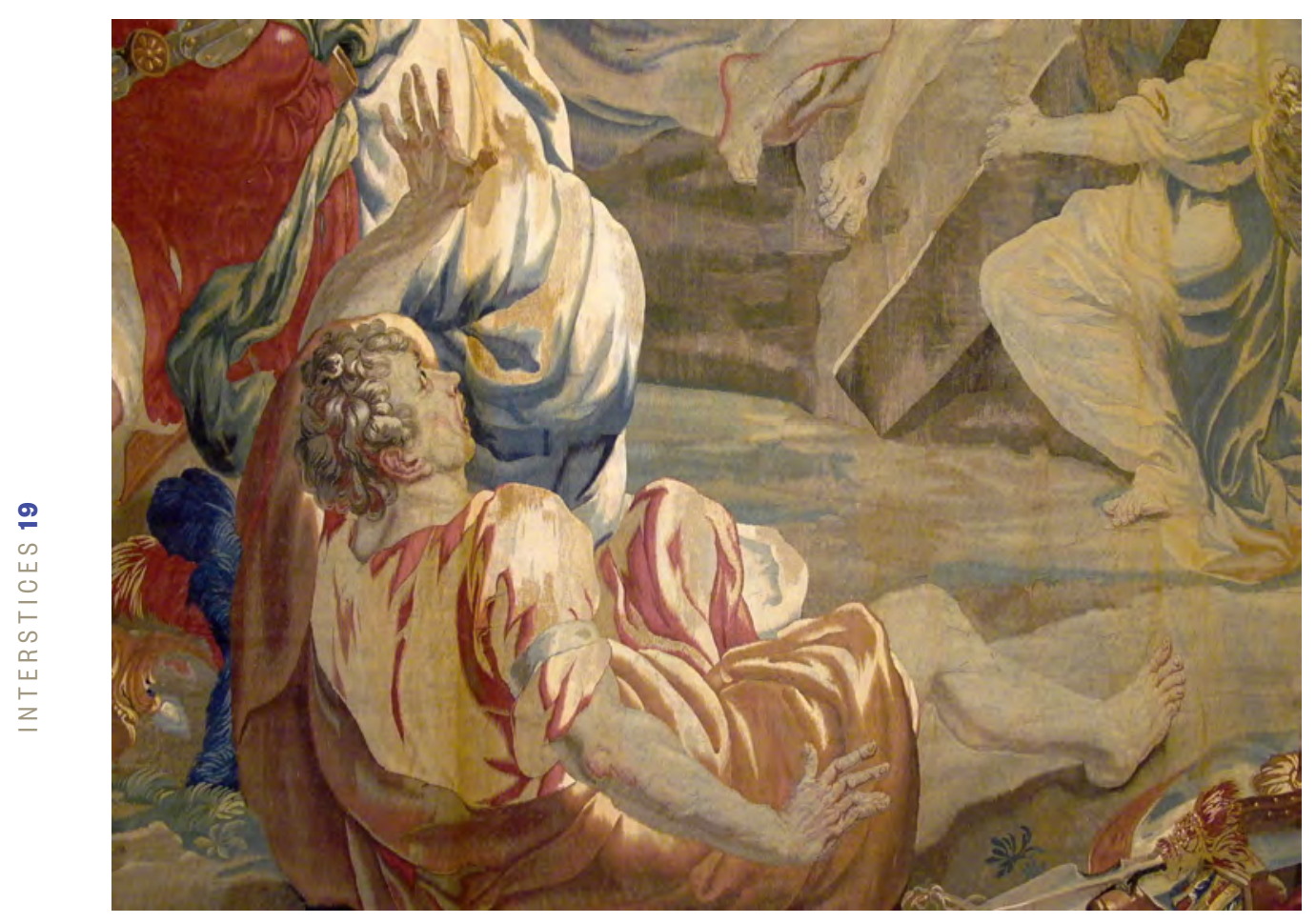

Fig. 11 Guillaume Dreyfuss. Peter Paul Rubens (1697-1700) The Resurrection of Our Lord, Detail, St John's co-Cathedral, Malta [Photograph]
In the early 1620s, Isabella, Infanta of Spain and Portugal and the Governor of the Spanish Netherlands (see Paranque, 2017) collaborated with Peter Paul Rubens to design a set of tapestries (see Fig, 11) that would illustrate the Triumph of the Eucharist and act as a tool to further counter the onslaught of the Reformation.

The set of monumental tapestries was presented by the Infanta to the Monasterio de las Descalzas Reales, where they were used to decorate the convent church on important occasions. Over half a century later, Ramon Perellos y Roccaful, on his election as Grand Master to the Order, commissioned a further set of the same tapestries as a gift to St John's co-Cathedral, a tradition that held sway for the two and a half centuries during which the Order of the Knights of St John of Jerusalem governed the island of Malta. His intention was probably to outshine the gifts of all previous Grand Masters and to add a soft and sumptuous touch to the interior of the church, whose walls, vault and floor had been, over the previous decades, covered with polychrome marble sepulchral slabs, gilded sculptural decoration and paintings by artists including Mattia Preti and Caravaggio. The twenty-nine tapestries were hung in the Cathedral every year between the feast of Corpus Christi and the feast of St John (De Giorgio 2018: 127).3 They are composed of three series: seven tapestries depict episodes of The Life of Christ from the New Testament; seven tapestries are allegorical representations of The Triumph of the Eucharist; and, the last fourteen represent the Twelve Apostles, the Virgin Mary and Christ Saviour (De Giorgio). If the richness and splendour of the tapestry series leave no doubt as to the intention by Ramon Perellos y Roccaful to impress his contemporaries, the intention behind the choice, in the late 17th century, of The Triumph of the Eucharist as one of the two main themes remains to be uncovered. Indeed, while Malta was affected by the Reformation in the first-half of the 16th century, the situation worsened considerably a few decades later following the construction of the new fortified city of Valletta (started in 1566), and the establishment of the Inquisition (Cassar, 1988: 51-68). Today the 
tapestries constitute the only full set of these designs by Rubens in the world, and are considered one of the greatest artefacts of the Baroque age. However, centuries of handling, inappropriate storage and harmful lighting and climatic conditions have left their toll on these rich, but delicate images made from silk, silver and gold threads. Further, today, with the Cathedral Museum exhibiting only six of the tapestries, the result is a loss of the larger narrative that celebrated the glory of the Roman Catholic Church then.

Our design in 2013 for the new museum enclosure consisted of blind walls, a requirement springing from the need to shut out all harmful natural UV light in the hall, itself measuring $50 \mathrm{~m}$ in length and $12 \mathrm{~m}$ in height. The enclosure was carved and articulated according to the classical use of the niche and rotated pilasters (see Fig. 12). Restricted by programmatic and conservation requirements, the core volume of the tapestry hall is carved at varying depths to produce an elaborate dialectic between the envelope-itself a container foregrounding divine absence-and the tapestries themselves celebrating the renewed presence of Christ through the Eucharist.

Pursued in the carved volume is an expression of the "dialectical tension of absence and presence" (Rasmussen, 2003: 154) resting on the intersection of two guiding principles of the Roman Catholic Church: the concept of transubstantiation (Crownfield, 1991) itself intrinsic to the sacrament of the Eucharist; and, the assertion of relics as figures of absence capable of catalysing popular fervour

Fig. 12 Ephraim Joris (2018). Monolith Sequence for St John's co-Cathedral Museum [Computer generated drawing: Joris/AP Valletta]

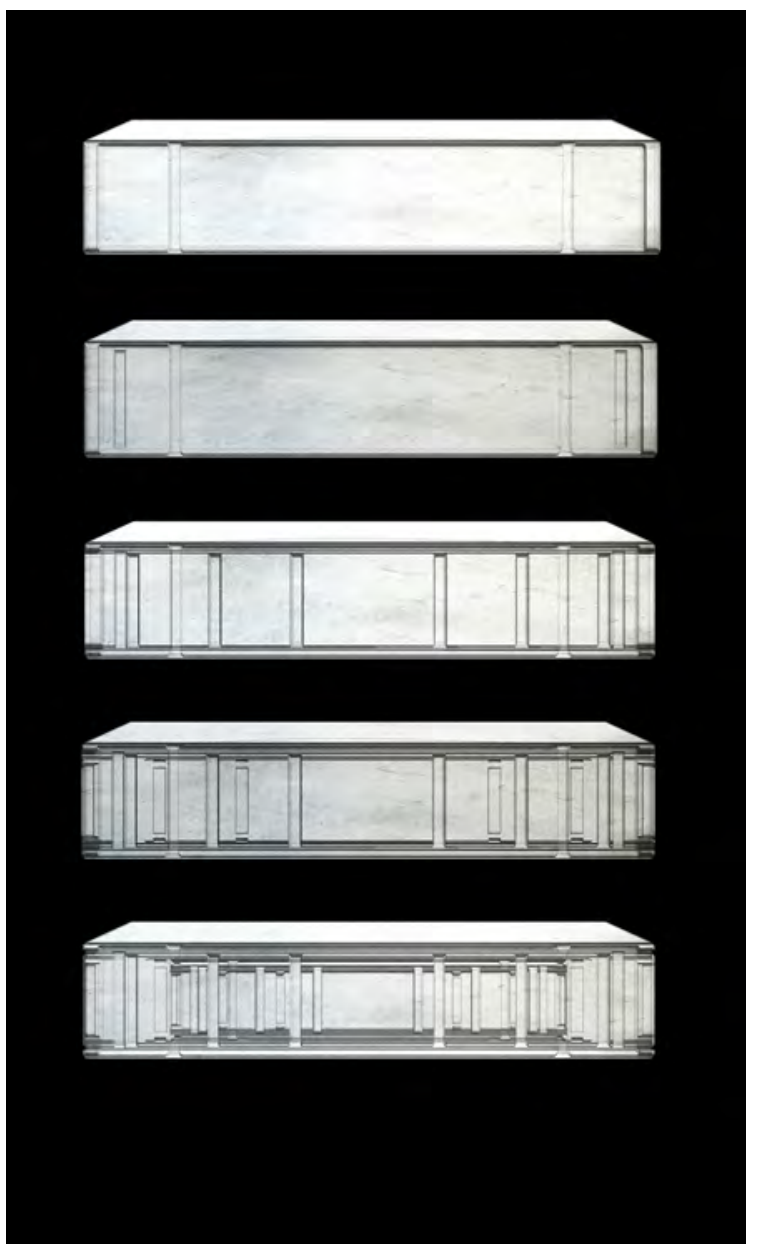




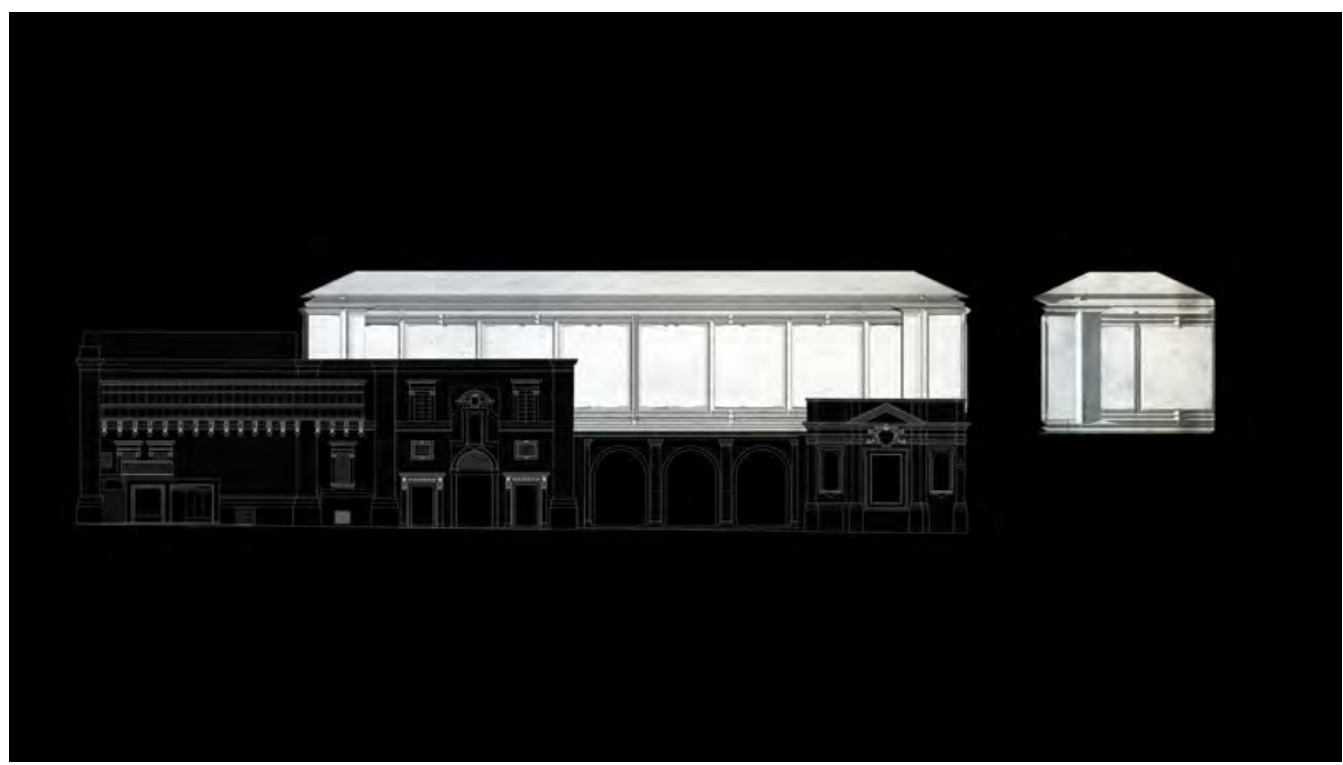

Fig. 13 Ephraim Joris (2018). Elevation showing the Monolith proposal in context for St John's co-Cathedral Museum [Computer generated drawing: Joris/AP Valletta] towards the faith more generally. The design for the carved volume then, simultaneously inferred references to Paleo-Christian sarcophagi and their layered architecture, something found in Medieval enamelled reliquary caskets of the 12th and 13th centuries too. What we anticipated for the volume, itself thought of as the lithic-core with blank panels, was a making visible of the invisible hosted within. In short, by surrendering the direct presence of a superior (divine) order, we focused instead on the task of making experienceable something that is absent-this being, in fact, one of the tenets of Christian architecture itself (Pérez-Gómez, 2016: 118). The resultant architecture, akin to a cephalophore carrying its own head and echoing the subtractive duplications of the earlier Monolith Drawing, lent to this space intended to house the relics, a corresponding presence of an absence (see Fig. 13). As such, the new extension was conceived of as a monumental reliquary containing the mystical narrative describing the principal mystery of the Catholic faith.

\section{The making present of absence}

More generally, the Monolith Drawing as a notation and generative system opens towards an architectural history inclusive of Modernism, one that people can enter as if a complex of multiple pasts and presents. Rather than a new conception, this aligns with an ancient capacity of architecture to imagine connecting narratives between the previous and the current (Augé, 1995). The Monolith Drawing itself collates form from within a field of intersecting, duplicating forces, thus acting analogously with the space of architectural history. Yet it learns from Modernism too, eschewing ornamentation as a design intent. In this way, architecture is made by means of a collision of matter through which intersecting forces become visible as they sculpt various intensities of space. This kind of drawing permits the expression of movement: an architecture of becoming, subject to unceasing change.

As has been demonstrated above, the relentless erosion of archetypical elements leads to a compositional language presencing domes and vaults despite their literal absence as such. Hence, the architectural figure is never erased, nor is it ever 
abstracted. Instead, the figure is isolated from its original narrative framework. Such isolation-given in the drawing by a pure black backing-opposes abstraction but aims for the undoing of the figurative task with which the architectural figures (columns, domes, and archivolts) have traditionally been burdened. Its figurative task, compliant with pre-set narratives, is halted, for within the Monolith Drawing, the figure enters a state of the figural, a term used by Foucault (1972) to describe a condition which is both non-figurative and non-abstract. This condition, where relations between the image as signifier and the object as that which is signified are broken, allowing for drawing to become matter. From within this material state-in fact the very pre-condition by which we are present at all-dark entries are split into open passages siting within architecture structures of loss. As each drawing develops in time, the marks of absence proliferate. The drawing thus shifts from being a medium in which architectural objects are represented to a medium expressing architecture in its becoming. So does the Monolith Drawing oscillate between representation and expression, rendering visible forces that are in themselves not visible.

The Monolith Drawing as applied to the St John's co-Cathedral Museum project has allowed the condensation of multiple design parameters and the articulation of the historical and spiritual values inherent to the project. Intersected at the site of drawing is the unravelling of forces within the memorial realm of an architectural consciousness that presences what has become, and must always be, absent. The resulting architecture, while responsive to its site and situation, draws out the flux inherent in the continuing historical dynamics of changing perception and beliefs. Using the Monolith Drawing as a primary investigative resource contributed here to develop an architecture in which individual consciousness can coincide with shared understanding, existing not as abstract form but as a figure freed from its previous task of figuration through the repeated process of multiple subtraction. The process of stereotomy enacted through mirroring \& subtraction, allows for a conversation between a lithic core-the initial architectural volume whose silhouette, in the case of the St John's co-Cathedral Museum project, is the delineation of site-specific boundaries - and a process of lithic reduction where mass is subtracted from the initial monolithic by choreographed process of mirroring. Form is, in the process, always an indirect product; lines are not actively drawn but are the outcome of the intersection of delineated site-historic margins. The resulting drawings of the St John's tapestry hall-with its carved exterior of blind doorways-aim at expanding on encounters with, and divergences from, form itself. The resulting architecture marks new areas of access, both physically and conceptually. The drawing is thus equal parts mind and material. The Monolith Drawing catalyses a process of drawing, and thus the contemplation of architecture, breaking the path of self-projection. As such, the architect as a determining self is subtracted from the drawing process per se. Excused from entering the drawing process as a personal agent, a meditative instrument is found instead, one that approaches a collective historical consciousness. 
Fig. 14 Ephraim Joris (2018) Monolith 16-07; A process of becoming

[Computer generated drawing, Joris/ AP Valletta]

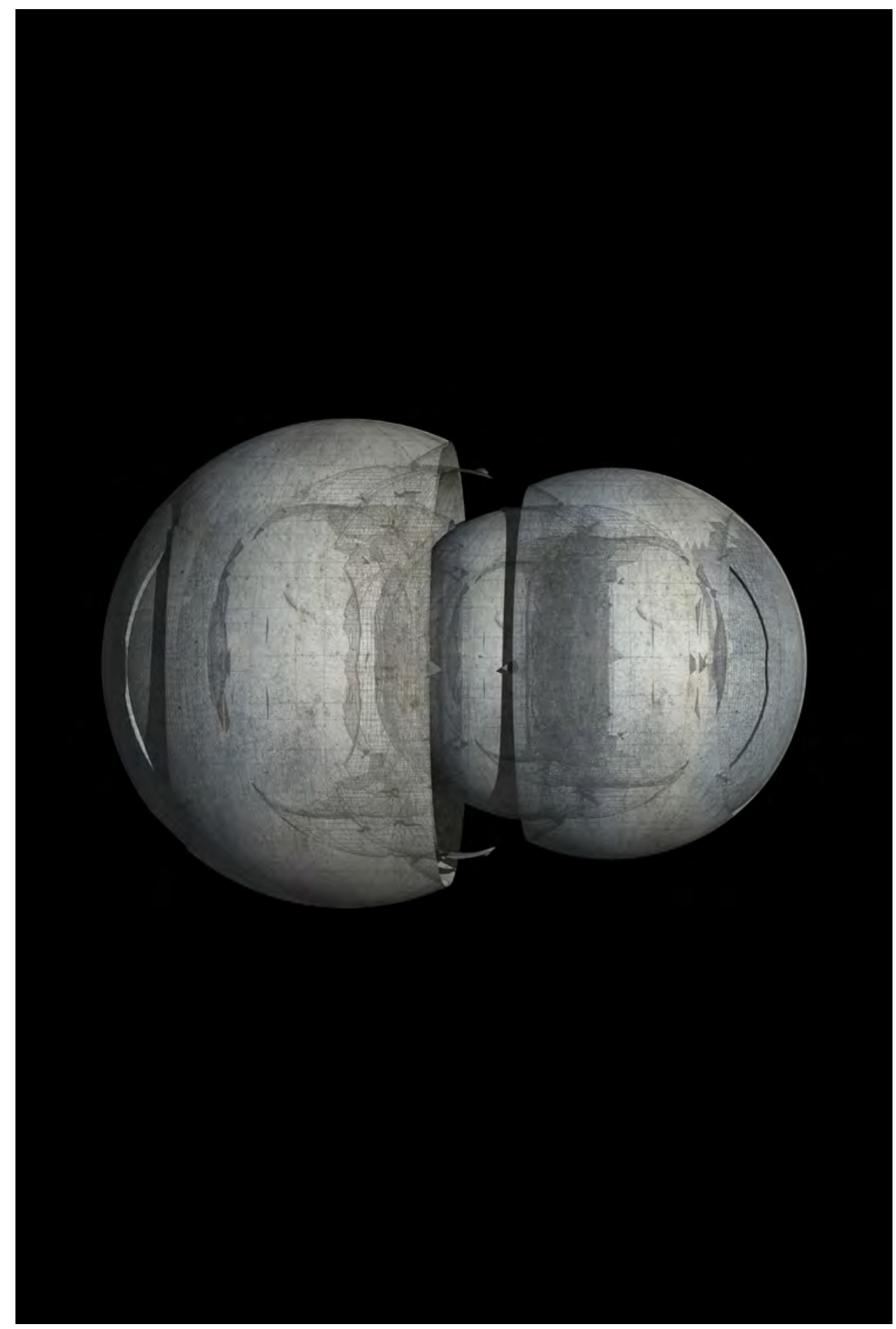


REFERENCES

Augé, M. (1995), Non-places: Introduction to an anthropology of Supermodernity (J. Howe, Trans.). Brooklyn, NY: Verso.

Barry, F. (2013). Ex Uno Lapide. The myth of the monolithic building in Antiquity. In K. Buhagiar, G. Dreyfuss, J. Bruenslow (Eds.), The Founding Myths of Architecture (pp. 57-72). London, UK: Artifice Books.

Cassar, C. (1988). The reformation and Sixteenth-Century Malta Melita Historica 10(1), 51-68.

Crownfield, D. (1991). The seminal trace: Presence, difference, and transubstantiation. Journal of the American Academy of Religion, 59(2), 361-371. Retrieved from http://www.jstor.org/ stable/1465501

1 Architecture Project (2016). Exhibition on The Monolith at Palo Alto (Barcelona) as part of exhibition/installation The RabbitDuck Illusion at Time Space Existence, Venice Biennale 2016.

2 Following a Bergsonian approach to time as non-linear. See for example Jancsary, J. (2019).

3 The feast of Corpus Christi celebrates the elements of transubstantiation, part of the Catholic faith. A moveable feast, it takes place in May or June depending on the liturgical calendar. The feast of St John takes place on June 24 .
De Giorgio, C. (2018). Hanging images for the last crusaders: The triumph of the Eucharist Tapestries and the Knights of Malta. In J. Azzopardi, D. R. Busuttil, A. Darmanin (Eds.), Tribute to Alain Blondy (pp. 123131). Malta: Fondation de Malte

Eisenman, P. (1999). Diagram diaries, London, UK: Thames \& Hudson Ltd.

Emmons, P., Kassem, D. (2014). Architect-computer symbiosis. Montreal Architectural Review, Vol 1, 47-65

Foucault, M. (1972). The archaeology of knowledge (A. M. Sheridan Smith, Trans.). NewYork, NY: Harper and Row.

Jancsary, J. (2019). The future as an undefined and open time: A Bergsonian approach. Axiomathes, 29, 61-80. https://doi org/10.1007/s10516-017-9364-0

Joris E. (2015). On longing: Rendering architecture through a consciousness accommodated by a collapse of time in space. (Unpublished doctoral thesis). RMIT, Melbourne.

Joris E. (2016a). On Longing: Rendering architecture through a consciousness of a collapse of time in space. In E. Joris (Ed.), Social Sciences \& Arts Conference Sgem Vienna Scientific Sessions: Book 4, Vol.2., 449-460.

Joris E. (2016b). The monolith drawing. In Joris, E. (Ed.), Between Paper and Pixels: Transmedial traffic in architectural drawing: Vol. 4.

Jung, C. (1922). Art as archetypal form. In L. Archie, J. G. Archie, Readings in the history of aesthetics: An open-source reader (pp. 408 - 420). Retrieved from https://philosophy.lander. edu/intro/artbook.pdf

Lavin, I. (1998). Ex Uno Lapide: The Renaissance sculptor's tour de force. In M. Winner, et al. (Eds.), ll cortile delle statue. Der Statuenhof des Belvedere im Vatikan (pp. 191-210). Mainz: Philipp von Zabern.

Nancy, J.-L. (1993). The birth to presence (B. Holmes, et al. Trans.). Stanford, CA: Stanford University Press

Paranque, E. (2017). Isabel Clara Eugenia, governor of the Spanish Netherlands: Trade, politics, and warfare, ruling like a king, 1621-1633. In E. Paranque, N. Probasco, C. Jowitt (Eds.) Colonization, piracy, and trade in early modern Europe: The roles of powerful women and queens (pp. 73-93). London, UK: Palgrave Macmillan.

Pérez-Gómez, A. (2016).

Attunement:Architectural meaning after the crisis of modern science. Cambridge, MA: The MIT Press.

Pollack, M. (2010). Cities at war in early modern Europe. Cambridge, UK: Cambridge University Press.

Rasmussen, B. G. (2003).

Presence and absence: Richard Hooker's sacramental hermeneutic. In W.J. Torrance Kirby (Ed.), Richard Hooker and the English Reformation (pp. 151164). Dordrecht: Springer.

Saint-Cyr, V. (2012). Creating a void or sublimation in Lacan. Recherches en psychanalyse, 13(1), 15-21.

Stross, B. (1996). The Mesoamerican cosmic portal: An early Zapotec example. RES: Anthropology and Aesthetics, No. 29/30, 82-101. Retrieved from http://www.jstor.org/ stable/20166944.

Tunbridge, J. (2009). Forging a European heritage: The role of Malta. Geographische Zeitschrift, 97(1), 12-23. Retrieved from http:// www.jstor.org/stable/25758630. 